\title{
The Impact of the Festival on the Image of the City
}

\author{
Ikrame Selkani* \\ University Mohammed V Rabat, Morocco \\ Submission: July 06, 2019; Published: September 10, 2019 \\ *Corresponding author: Ikrame Selkani, University Mohammed V Rabat, Morocco
}

Keywords: Economic; Cultural; Festivals; Social

\section{Mini Review}

When the culture is introduced in some territory, different economic actors come into connection and begin to relate to improve the territory itself, for an improvement of local development. Culture is an opportunity for a real position where local actors make a huge effort to represent this territory with a positive image and to obtain very favorable economic, social and media results. In this sense, Xavier Greffe [1] reminds us in his report on "the cultural attractiveness of the territory" (2006), that some studies have established a very strong correlation between economic development and cultural development in the French regions "the regions with a minor advance quickly in the last twenty years are those in which the weight of cultural activities has also progressed more slowly Taliano des Garets F [2].

It is evident that major events, such as festivals, can influence the confirmation of the image of the organizing city using its favorable perception as a potential travel destination [3-5]. Festivals contribute to the improvement of the image of the Edimburgh International Festival, New Orleans, Mardi Gras). The organization of the festivals can be the last stage to end the negative reputation of the city and start with a new page. Festivals attract people and tourists and remove the negative image. The festivals have the advantage of improving the image of the city as the case of Germany after the Second World War, with the Olympic Games in Munich in 1972, and the image of Japan, after the Second World War, when it organized the event of the Olympic Games in Tokyo in 1964.

In short, the image of the city is one of the most important factors in the field of territorial marketing so that the image of the spiral is strongly related to the City marketing tool. Given the great competition that exists between cities and the speed of the phenomenon of globalization, which was manageable for large cities, it has been unfortunately difficult and complicated for medium and small cities. Consequently, this phenomenon forced all cities and regions to redefine themselves and look again to improve the image and make it more attractive.

This effort put into the image will allow the city to compete internationally to attract tourists, investors, and organize conferences, events [6-13]. Nowadays, one of the most important issues is to take care of the image of the city. It is an essential function of the local authorities, and for this reason the latter realized that the more investment is made in the development and the improvement of the image of the city, the latter will increase more and will be more attractive. In the field of business, social activities, tourism ... the importance of the image of the city is enormous in a way that generates a mental image about it that becomes an important component of future success or failure $[6,14]$.

Festivals are considered as essential elements, because they play a crucial role in improving the image of the organizing city of the event, in a relatively short period of time [15]. During the last two decades, festivals have been considered as an effective tool for urban policy and are intended to stop the decline of a geographical area by positively regenerating its image and increasing its attractiveness for tourists and residents alike [10,15,16]. From the nineties, several authors believed that there was a relationship between the place occupied by culture within the territory and the importance of regional development.

"The matter is extremely serious; we are convinced that culture will be the motor of tomorrow" [17]. For DiMeo (2001), "the territory is steeped in cultural values, each reflecting the affiliation to a localized group", then [1], indicates that culture exerts a very large economic influence on local development. 
because culture transmits symbols and presents a strong value in communication "and by the same author:" several territories in difficulties find their way thanks to cultural activities that help them find an opportunity to create new activities ".

After two years [18], it shows culture as an element of the structuring of a territory and as an asset capable of favoring the creation of other activities, with culture we can transmit a capacity for reflection in a territory, of creation and of a project that will exceed the only artistic sector to take advantage of most of the activities. OECD (2005) stipulated that culture contributes to local development, making it an attractive place for its inhabitants and visitors, influencing the creation of products associating aesthetic and useful dimensions.

Culture is the "factory" of the territory Kahn [19], for Santaga [20] culture and territory form an indivisible and native binomial: a territory is both a social place and a place for the production of activities economic, which are influenced by the culture of the territory. In order to make a difference as a visitor or cultural tourist, we must differentiate ourselves from the competition by presenting and offering a "specific" product Pecqueuur [18]. Culture and economics are two spheres that have been ignored for a long time or "more or less two phenomena separated in the opposite way" [21]. Historically a difficult field to assimilate.

Economic analysis (according to the findings of Ricardo, Marshall and Keynes, in particular), culture was the subject of an early interest on the part of the economists of the seventies, when they sought to measure the economic importance of cultural activities. This is explained as much by the progress of the economic analysis as by the developments in the cultural field and the impact of new technologies in the production and distribution of cultural products. Nowadays it seems accepted that the atypical properties of cultural goods have allowed conceptual advances Farchy and Sagot-Duvauroux [22]; so when we have sought to integrate the economy into the reality of the market economy (heterogeneity of the product, imperfect information ...) and be free of inappropriate assumptions to analyze the consumption of commercial products (the likes of stability, the decrease of marginal utility ...), culture was seen as an adequate field of evidence for new theoretical advances. The existence of multiple and complex relations between economy and culture can be seen now, as to suggest "a quite marked convergence between economy and culture in modern capitalism" [22] or a recursive loop [23]; "Nowadays, the fruits of knowledge, information, science and culture can be fully valued and, probably, these intangible riches are the most strategic resources that are in the context of the globalization of the economy" [19].

According to the 12th edition of the World Day of Cultural Diversity for dialogue and development on May 21, 2013, the universal declaration on cultural diversity, Unesco stipulated that: "Placing culture at the core of development constitutes an investment in coming from the world and the condition of the success of a well understood globalization that takes into consideration the principles of cultural diversity ". In fact, culture is not only that area that does not matter and that is always in third or fourth level. On the contrary, culture today has become a key to success, which must be included in the overall development of each territory of each country.

Most of the cultural investments made by a territory allow it to better define its identity and create real social cohesion among citizens Yudice [24]. In this way, the products and cultural activities help to take the historical image and to offer the pleasure the beauty and the true soul of this territory to all the citizens first, and then to the cultural tourists. Most of the cultural investments made by a territory allow it to better define its identity and create real social cohesion among citizens [24]. In this way, the products and cultural activities help to take the historical image and to offer the pleasure the beauty and the true soul of this territory to all the citizens first, and then to the cultural tourists.

The cultural manifestations classify the public into young people, adults, men, women, nationality, age, religion ... In other words, culture has become a device that helps territories: cities or regions, to be conceived as a brand that can attract visitors and cultural tourists [25,26]. Territorial marketing oriented towards cultural events is executed by making a connection between the public sector, the private sector and voluntary organizations [27]. Until today, culture is not really considered by political and economic actors as a true factor for development, culture is a set of distinctive, spiritual, material features ... that characterize a territory or a group of people. The latter includes, apart from the arts, ways of life, traditions and beliefs. In this way, culture plays a very important role alongside tourism in achieving the objectives of sustainable and sustainable economic growth.

In fact, local development according to [1] It is a process of diversification and enrichment of economic and social activities in a territory, the mobilization and coordination of resources and energies A product of the efforts of its population, this will call into question the existence of a project to develop the integration of its economic, social and cultural components and will make a space of continuity, "active solidarity". Therefore, one of the strategies that a territory could follow alongside a territorial marketing process is a local development strategy, valuing its history and heritage and reinforcing its tourist attractiveness. A series of practices has been implemented that help to evolve the sectors and the different areas connected to these activities by mobilizing local actors (companies, associations ...), investing in the field of culture and helping to give new life to such territories. as a tool and a source of new investment ideas [28].

One of the most important things is to make the public loyal towards the cultural events that they carry out within that territory, especially giving them the desire to return. In effect, the consent of the participation of the local population is a very important and essential real initiative for a real strong identity of said territory from its citizens and its local actors. Although the cultural manifestations have an international form, it is necessary 
to involve the local population that increases the dynamics towards the project itself, so that it is more a collective work, favoring a solidary atmosphere. Throughout this chapter we will develop in a first time a section to talk about the different products and cultural events and then a second section developing the role of the festival in the success of the management of the territory.

\section{References}

1. Greffe X (2006) L'économie de la Culture: Lecture Artistique ou Lecture Industrielle? Ministère de la Culture-DEPS, pp. 29-71.

2. Taliano Des Garets F (2007) Les Métropoles Régionales et la Culture: 1945-2000. Comité d'histoire du ministère de la Culture et des Institutions culturelles/La documentation française, p. 304.

3. Sassen S, Roost F (1999) The city: strategic site for the global entertainment industry. The tourist city, pp. 143-154.

4. Judd DR, Fainstein SS (1999) The tourist city. Yale University Press, USA.

5. Selby J, Bradley B (2003) Action research intervention with young people: a city council's response. Australasian Psychiatry 11(sup1): S122-S126.

6. Ashworth GJ, Voogd H (1990) Selling the City: Marketing Approaches in Public Sector Urban Planning. Belhaven Press.

7. Bradley A, Hall T, Harrison M (2002) Selling Cities: Promoting New Images for Meetings Tourism. Cities 19(1): 61-70.

8. Gold J (1994) Locating the message: Place promotion as image communication. in Gold J and Ward S (eds). Place Promotion: The Use of Publicity and Marketingto Sell Towns and Regions. John Wiley \& Sons, Toronto.

9. Kotler P, Haider DH, Rein I (1993) Attracting Investment, Industry, and Tourism to Cities, States and Nations-Marketing Places. The Free Press How to measure the economic impact of mega-events-World Economic Forum Davos. New York.

10. Short JR, Kim YH (1998) Urban representations: selling the city in difficult times. In: T Hall, P Hubbard (Eds.), In the Entrepreneurial City: Geographies of Politics, Regime and Representation. John Wiley, Sons, Chichester, UK, pp. 55-75.

11. Young C, Lever J (1997) Place Promotion, Economic Location and the Consumption of Image. Tijdschrift Voor Economicische en Sociale Geografie 88: 332-341.

12. Paddison R (1993) City marketing, Image Reconstruction and Urban Regeneration. Urban Studies 30(2): 339-350.

13. Morgan N, Pritchard A (2002) Contextualizing destination branding. In Destination Branding: Creating the Unique Destination Proposition.
In: SP Morgan, S Pritchard, R Pride (Eds.), Butter worth-Heinemann, Woburn, MA.

14. Casellas A, Jutgla ED, Pallares-Barbera M (2010) Creación de imagen, visibilidad y turismo como estrategias de crecimiento económico de la ciudad. Finisterra 45(90).

15. Getz D (1991) Festivals, special events, and tourism. Van Nostrand Reinhold.

16. Quinn B (2005) Arts festivals and the city. Urban studies 42(5-6): $927-$ 943.

17. Uhrich R (1994) Villes et culture. Revue d'Economie Régionale et Urbaine (5): 869-878.

18. Landel PA, Pecqueur B (2009) La Culture Comme Ressource Territoriale Spécifique. Administration et Politique: une Pensée Critique sans Frontières. Dialogue avec et autour de Jean-Jacques Gleizal, pp. 181192.

19. Kahn R (2007) Une Approche Pluridisciplinaire de la Dimension Culturelle du Développement Territorial. Les Dynamiques Territoriales Débats et Enjeux Entre les Différentes Approches Pluridisciplinaire.

20. Santaga W (2008) Dimensions Spatiales de la Créativité, Communication 3eme Journées d'économie de la Culture Nouvelles Frontières de Économie de la culture, Paris.

21. Scott AJ, Leriche F (2005) Les Ressorts Géographiques de L'économie Culturelle: du local au Mondial. L’espace Géographique 34(3): 207-222.

22. Farchy J, Sagot Duvauroux D (1994) Economie des politiques culturelles, Paris, Presses Universitaires de France. France.

23. Alcaras JR, Blanchet P, Joubert J (2001) Cultures Régionales et Développement Économique. In Annales de la Faculté de droit d'Avignon. pp. 293-305.

24. Yudice G (2007) Economia da cultura. Paper presented at the International Seminar on Cultural Diversity, Ministerio da Cultra do Brazil, Sao Paulo.

25. Anholt Simon (2008) Place branding: Is it marketing, or isn't it? Place Branding and Public Diplomacy, 4(1): 1-6.

26. Hudson Simon, Ritchie JR (2009) Branding a memorable destination experience. The case of Brand Canada. International Journal of Tourism Research 11(2): 217-228.

27. Hellgren B, Stjernberg T (1995) Design and Implementation in Major Investments-a Project Network Approach. Scandinavian Journal of Management 11(4): 377-394.

28. Kim H, Borges MC, Chon J (2006) Impacts of Environmental Values on Tourism Motivation: The Case of FICA Brazil. Tourism Management 27(5): 957-967. 
$@$

This work is licensed under Creative Commons Attribution 4.0 License

DOI:10.19080/ASM.2019.04.555634
Your next submission with Juniper Publishers will reach you the below assets

- Quality Editorial service

- Swift Peer Review

- Reprints availability

- E-prints Service

- Manuscript Podcast for convenient understanding

- Global attainment for your research

- Manuscript accessibility in different formats ( Pdf, E-pub, Full Text, Audio)

- Unceasing customer service

Track the below URL for one-step submission https://juniperpublishers.com/online-submission.php 